\title{
Defined shear and heat treatment of apple pomace: impact on dietary fiber structures and functional properties
}

\author{
Vera Schmid ${ }^{1} \cdot$ Antje Trabert $^{2} \cdot$ Judith Keller ${ }^{2} \cdot$ Mirko Bunzel $^{2} \cdot$ Heike P. Karbstein $^{1} \cdot$ M. Azad Emin ${ }^{1}$
}

Received: 11 March 2021 / Revised: 2 May 2021 / Accepted: 9 May 2021 / Published online: 27 June 2021

(c) The Author(s) 2021

\begin{abstract}
Food by-products can be modified by extrusion processing. However, the impact of thermal and mechanical stress, respectively, on the structure and thus functional properties of dietary fiber-rich food by-products is still unknown. In the extrusion process, thermal and mechanical stress are coupled, not constant, and difficult to measure or calculate. Thus, their influence on structural changes and functional properties cannot be evaluated separately. In this work, a specific shear cell, denoted by closed cavity rheometer, was used to treat apple pomace with defined thermal and/or mechanical stress. Dietary fiber composition and fiber polysaccharide structures appeared to be more susceptible to high temperatures than mechanical stress. With increasing temperature (and mechanical stress) soluble and low-molecular-weight soluble dietary fiber contents increased, whereas insoluble fiber contents decreased. Arabinans as rhamnogalacturonan type I polysaccharides and galacturonic acid containing pectic polysaccharides were identified as being most susceptible to degradation under these conditions. Furthermore, the defined treatment affected the functional properties. Although changes in the water solubility index (WSI) and/or the water absorption index (WAI) were not detected up to $90^{\circ} \mathrm{C}$, WSI and WAI decreased significantly at a treatment temperature of $120^{\circ} \mathrm{C}$. However, at very high temperatures $\left(160^{\circ} \mathrm{C}\right)$, WSI and WAI increased. The application of shear and longer treatment times resulted in higher WSI values and complex viscosities as compared to low shear stress.
\end{abstract}

\section{Graphic abstract}

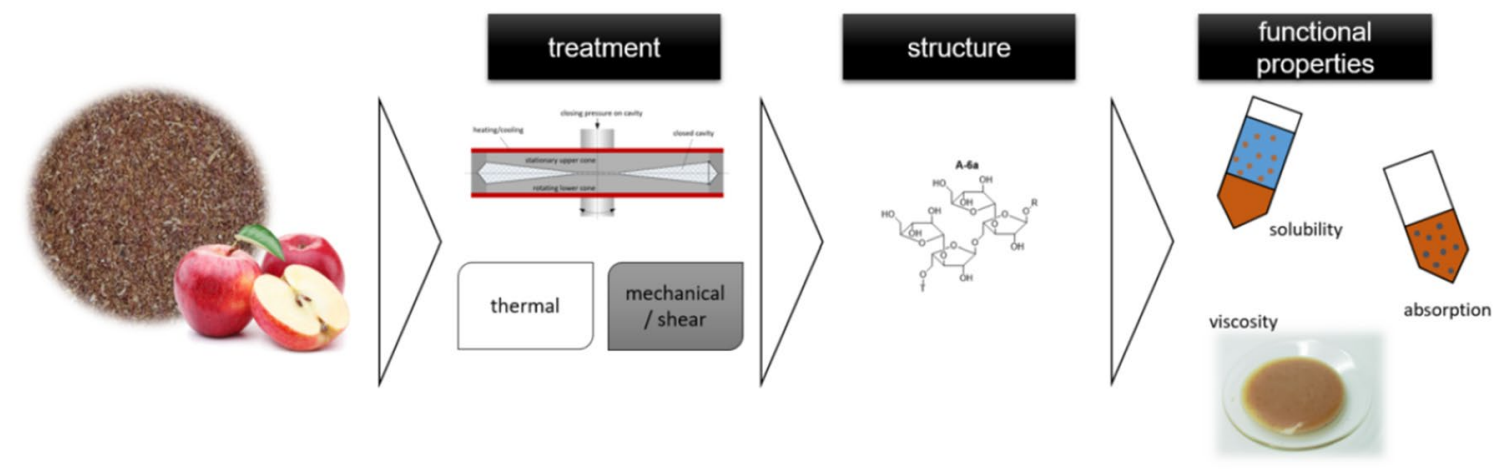

Keywords Cell wall polysaccharides $\cdot$ By-products $\cdot$ Rheological properties $\cdot$ Viscosity $\cdot$ Closed cavity rheometer

\section{Introduction}

Vera Schmid and Antje Trabert contributed equally to this study.

M. Azad Emin

azad.emin@kit.edu

Extended author information available on the last page of the article
Extrusion processing can be used to modify the molecular structure and thus the techno-functional properties of by-products from food processing industries such as apple pomace [1-3]. Apple pomace is a by-product of the juice processing industries, which is mostly discarded. It mainly 
consists of peel (exocarp), flesh/pulp (mesocarp) remnants, endocarp, seeds, and peduncle [4], thereby being a good source of phytochemicals and dietary fiber [2, 5-7].

Dietary fiber is mostly made up of plant cell wall polymers, which vary widely depending on plant taxonomy, plant organ, and plant maturity. Polysaccharide composition and their chemical structures determine both the nutritional and functional properties of dietary fiber. During extrusion processing, dietary fiber is subjected to high temperatures (up to $200^{\circ} \mathrm{C}$ ) and mechanical stress (up to $5000 \mathrm{~s}^{-1}$ depending on absolute water content) [8]. It is well-known that thermomechanical treatment affects the molecular weight and structure of dietary fiber polysaccharides. Previous studies showed that extrusion processing increased soluble dietary fiber (SDF) content and changed the monosaccharide composition of both insoluble dietary fiber (IDF) and SDF polysaccharides. It was demonstrated that pectic polymers especially arabinose and galacturonic acid containing subunits in the insoluble and soluble fraction were most susceptible to thermomechanical stress [3]. As a result of thermomechanical stress, techno-functional properties, i.e., water binding and gelling properties changed, too. Water solubility and water absorption indices of apple pomace depend on the applied process conditions [3,9]. Modified dietary fiber offers both nutritional and functional properties and may substitute commercial food additives. The application of byproducts can therefore meet consumers' demand for healthpromoting, sustainable food and food additives contributing to zero-waste lifecycle [10].

In extrusion processing, applied thermal and mechanical stresses are not constant and coupled to each other. Also, they are very difficult to measure [11]. Varying material temperature along the extruder results in a spontaneous change in melt viscosity and thus affects mechanical stress. Furthermore, shear rates and temperatures vary along the screw radius [8].

In order to design the extrusion process in such a way that the functional properties of the pomace can be altered in a targeted manner, the individual impact of both thermal stress and mechanical stress must be known in detail. Therefore, these parameters have to be decoupled.

Thus, the scope of this study was to investigate the effect of defined thermal and/or mechanical stress on content and chemical structure of apple pomace dietary fiber and its individual soluble and insoluble polysaccharides as well as on resulting functional properties of apple pomace. To achieve these goals, a specialized rheometer (i.e., closed cavity rheometer, CCR) was used that is able to provide defined mechanical and thermal treatment conditions.

\section{Materials and methods}

\section{Materials, chemicals, and reagents}

Apple pomace was kindly provided by Herbafood Ingredients GmbH (Company of H\&F-Group, Werder (Havel), Germany). Detailed information about dietary fiber contents, chemical composition, and polysaccharide structures is given in Schmid et al. [3]. All chemicals and reagents were of analytical grade and purchased from Carl Roth (Karlsruhe, Germany), Merck (Darmstadt, Germany), Sigma Aldrich (St. Louis, MO, United States), or VWR (Radnor, PA, USA). Thermostable $\alpha$-amylase Termamyl $120 \mathrm{~L}$ (EC 3.2.1.1, from Bacillus licheniformis, $120 \mathrm{KNU}$. $\mathrm{g}^{-1}$ ), the amyloglucosidase AMG $300 \mathrm{~L}$ (EC 3.2.1.3, from Aspergillus niger, $300 \mathrm{AGU} \mathrm{g}^{-1}$ ), and the protease Alcalase 2.5 L (EC 3.4.21.62, from Bacillus licheniformis, $2.5 \mathrm{AU} \mathrm{g}^{-1}$ from Novozymes (Bagsværd, Denmark) were used for preparative dietary fiber isolation. A thermostable $\alpha$-amylase (EC 3.2.11, from Bacillus licheniformis, $3000 \mathrm{U} \mathrm{mL}^{-1}$ ) and an amyloglucosidase (EC 3.2.1.3 from Aspergillus niger) (Megazyme, Bray, Ireland) were used to analyze starch contents. These enzymes in addition to a protease (EC 3.4.21.14 from Bacillus licheniformis) (Megazyme, Bray, Ireland) were used for the analytical dietary fiber analysis excluding resistant starch.

\section{Sample preparation and thermomechanical treatment}

Apple pomace was dried in a vacuum dryer at $25^{\circ} \mathrm{C}$ and 8 mbar to remove residual moisture. The dried apple pomace was adjusted to a water content $\left(\mathrm{w}_{\mathrm{H} 2 \mathrm{O}}\right)$ of 10 , 20 , and $40 \%(\mathrm{w} / \mathrm{w})$ by using a Thermomix (Vorwerk, Wuppertal, Germany). Water was added over $30 \mathrm{~s}$ at low speed $\left(500 \mathrm{~min}^{-1}\right)$, and the blend was treated for $1 \mathrm{~min}$ at medium speed $\left(2000 \mathrm{~min}^{-1}\right)$. Hydrated apple pomace was sealed in a vacuum bag and stored at $8{ }^{\circ} \mathrm{C}$ for $72 \mathrm{~h}$ to ensure homogeneous hydration.

For thermal or/and mechanical treatment a closed cavity rheometer (CCR; RPA Flex, TA Instruments, New Castle, Delaware, USA) was used. Figure 1 shows a schematic illustration of the used rheometer.

Approx. $5 \mathrm{~g}$ of hydrated apple pomace were placed in the cavity and closed with a pressure of $450 \mathrm{kPa}$. The cavity was sealed with a rubber gasket to avoid water evaporation during the treatment. The surface of the upper and lower cone has grooves to prevent slippage; however, only the lower cone oscillates. Parameters used for thermal and/ or mechanical treatment of apple pomace are shown in Table 1. 


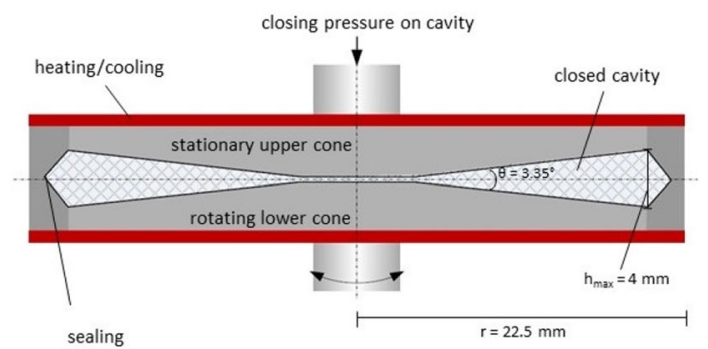

Fig. 1 Schematic illustration of the closed cavity rheometer (CCR) used for thermal, mechanical, and thermomechanical treatment

Five to six sample disks of each treatment were taken for offline measurements such as water solubility and viscosity of dispersions. Before being analyzed, samples were dried in a vacuum dryer at $25^{\circ} \mathrm{C}$ and 8 mbar to a constant mass, milled in a coffee mill M55 (Petra Electric, Jettingen-Scheppach, Germany), sieved to a particle size of $140<x<280 \mu \mathrm{m}$, and vacuum dried.

Six samples were chosen for further chemical/structural analyses. For simplification, these samples were named as follows: A: $120^{\circ} \mathrm{C}, 10 \%$ water; $1 \mathrm{~min}, 150 \mathrm{~s}^{-1}$; B: $120^{\circ} \mathrm{C}$, $10 \%$ water; $6 \mathrm{~min}, 150 \mathrm{~s}^{-1}$; C: $120^{\circ} \mathrm{C}, 10 \%$ water; $1 \mathrm{~min}$, $0.001 \mathrm{~s}^{-1}$; D: $160{ }^{\circ} \mathrm{C}, 10 \%$ water; $1 \mathrm{~min}, 0.001 \mathrm{~s}^{-1}, \mathrm{E}$ : $160{ }^{\circ} \mathrm{C}, 10 \%$ water; $1 \mathrm{~min}, 150 \mathrm{~s}^{-1}$; F: $160{ }^{\circ} \mathrm{C}, 40 \%$ water; $1 \mathrm{~min}, 0.001 \mathrm{~s}^{-1}$.

\section{Chemical/structural analysis}

Quantitative data are presented as mean \pm standard deviation $(n=3)$. Semiquantitative structural analyses of isolated IDF and SDF (molecular weight distribution, monosaccharide composition, glycosidic linkage analysis) were performed in duplicate and given as mean \pm range/2 $(n=2)$.

\section{Free mono- and disaccharides}

To analyze contents of free mono- and disaccharides (glucose, fructose, sucrose, and maltose) an aqueous extraction was performed $(200 \mathrm{mg} / 10 \mathrm{~mL})$. Sonication (temperature $<30^{\circ} \mathrm{C}$ ), vortexing, and repetition (four times, using fresh water each) supported the extraction process. Extracts were filtered (PTFE $45 \mu \mathrm{m}$ ), and an aliquot was taken to precipitate co-extracted polymers by using four times the amount of ethanol. Following evaporation of the separated supernatant, the residue was redissolved in water, D-fucose was added as an internal standard, and the solution was analyzed by using high-performance anion exchange chromatography with pulsed amperometric detection (HPAEC-PAD) [3, 12].

\section{Starch content}

Starch contents were quantitatively determined by analyzing enzymatically liberated glucose using HAPEC-PAD: Samples $(1 \mathrm{~g})$ were treated in a $0.08 \mathrm{M}$ phosphate buffer $(50 \mathrm{~mL}$, $\mathrm{pH}$ 6.0) for $15 \mathrm{~min}$ at $60^{\circ} \mathrm{C}$, followed by enzymatic digestion using thermostable $\alpha$-amylase $\left(3000 \mathrm{U} \mathrm{mL}^{-1}, 92^{\circ} \mathrm{C}\right.$, $15 \mathrm{~min})$ and amyloglucosidase $\left(36,000 \mathrm{U} \mathrm{g}^{-1}, \mathrm{pH} 4.5,60^{\circ} \mathrm{C}\right.$, $15 \mathrm{~min})$. To remove interfering compounds by Carrez clarification, $1 \mathrm{~mL}$ of each Carrez reagent (Carrez I solution: $150 \mathrm{~g}$ $\mathrm{L}^{-1} \mathrm{~K}_{4}\left[\mathrm{Fe}(\mathrm{CN})_{6}\right] \times 3 \mathrm{H}_{2} \mathrm{O}$; Carrez II solution: $300 \mathrm{~g} \mathrm{~L}^{-1}$ $\mathrm{ZnSO}_{4} \times 7 \mathrm{H}_{2} \mathrm{O}$ ) was added, and the $\mathrm{pH}$ value was adjusted to 7.5-8.0. After centrifugation, supernatants were diluted, D-fucose was added as an internal standard, and the solution was analyzed by HPAEC-PAD [3, 12].

\section{Dietary fiber analysis}

IDF, SDF, and low-molecular-weight soluble dietary fiber (LMW-SDF) were determined after enzymatic digestion with thermostable $\alpha$-amylase, amyloglucosidase, and protease, applying a combination of the procedures AOAC 985.29 [13] and AOAC 2009.01 [14]. IDF and SDF were determined gravimetrically, and their contents were corrected for ash and residual protein [15]. LMW-SDF were analyzed from the SDF filtrates after desalting using a mixed ion exchange column. The desalted solution was evaporated, redissolved in water and analyzed by HPLC (Hitachi, Merck, Darmstadt, Germany) with refractive index (RI) detection (Knauer, Berlin, Germany) using two size exclusion columns
Table 1 Parameters for thermomechanical treatment. Listed shear and treatment times were applied at various treatment temperatures and water contents

\begin{tabular}{llllll}
\hline Temperature $\mathrm{T}_{\mathrm{CCR}} /{ }^{\circ} \mathrm{C}$ & Water content $\mathrm{w}_{\mathrm{H} 2 \mathrm{O}} / \%$ & Time $\mathrm{t} / \mathrm{min}$ & $\begin{array}{l}\text { Fre- } \\
\text { quency f/ } \\
\mathrm{Hz}\end{array}$ & $\begin{array}{l}\text { Strain } \gamma / \% \\
\text { Maximum } \\
\text { shear rate } \dot{\gamma} \\
/ \mathrm{s}^{-1}\end{array}$ \\
\hline $60 ; 90 ; 120 ; 160 ; 180$ & $10 ; 20 ; 40$ & $1 ; 3 ; 6 ; 10$ & 0.1 & 0.14 & 0.001 \\
& & 10 & 40.04 & 25 \\
& & 10 & 79.65 & 50 \\
& & 10 & 160 & 100 \\
& & 10 & 239.94 & 150 \\
\hline
\end{tabular}


in series (TSKgel G2500PWxl, $300 \mathrm{~mm} \times 7.8 \mathrm{~mm}$, particle size $7 \mu \mathrm{m}$, Tosoh, Tokyo, Japan) [3].

\section{Preparative dietary fiber isolation}

Preparative isolation of IDF and SDF was performed following the principles of the AOAC 985.29 method (enzymatic treatment using thermostable $\alpha$-amylase, protease, and amyloglucosidase) with minor modifications as described by Bunzel et al. [16].

\section{Molecular weight distribution}

The molecular weight distribution of SDF polymers was determined by dissolving SDF in $50 \mathrm{mM}$ sodium nitrate for $24 \mathrm{~h}$ at $40{ }^{\circ} \mathrm{C}$, followed by centrifugation and separation of the supernatant according to hydrodynamic volume using two size exclusion columns in series (TosohTSK-gel G6000PWxl $300 \mathrm{~mm} \times 7.8 \mathrm{~mm}$, particle size $13 \mu \mathrm{M}$; TSKgel G4000PWxl $300 \mathrm{~mm} \times 7.8 \mathrm{~mm}$, particle size $10 \mu \mathrm{M}$ ) and a guard column (TosohTSK-gel PWxl $40 \mathrm{~mm} \times 6.0 \mathrm{~mm}$, particle size $12 \mu \mathrm{M}$ ). Sodium nitrate was used as eluent (flow

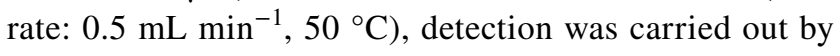
HPLC-RI (Hitachi, Merck, Darmstadt, Germany) [17].

\section{Polysaccharide composition}

Monomer composition Analysis of the monomer composition was performed according to Schmid et al. 2020b [3] as briefly described in the following: To determine the monosaccharide composition of IDF polysaccharides, monomers were released by a two-step sulfuric acid hydrolysis and analyzed by HPAEC-PAD. The corresponding monomer compositions of SDF polysaccharides were determined using methanolysis followed by trifluoroacetic acid (TFA) hydrolysis. LMW-SDF monomers were determined after mono- and disaccharides were removed from SDF supernatants on a semipreparative scale by using HPLC (Hitachi, Merck, Darmstadt, Germany) with RI detection (Knauer, Berlin, Germany). LMW-SDF oligo-/polysaccharides were hydrolyzed using TFA, and the liberated monosaccharides were analyzed by HPAEC-PAD.

Methylation analysis Glycosidic linkages of IDF and SDF polysaccharides were analyzed by using methylation analysis [3]. In brief, samples were dissolved in DMSO and methylated twice by using methyl iodide and $\mathrm{NaOH}$. Methylated polysaccharides were extracted into dichloromethane, and the solvent was removed by evaporation. TFA hydrolysis for $90 \mathrm{~min}$ at $121{ }^{\circ} \mathrm{C}$ was followed by reduction with sodium borodeuteride and acetylation using acetic anhydride and 1-methylimidazole [18]. Identification and semiquantitative determination of the result- ing partially methylated alditol acetates were carried out by using GC-MS and GC-FID, respectively, using molar response factors according to Sweet et al. [19].

\section{Water solubility index/indices (WSI) and water absorption index/indices (WAI)}

The water solubility index as well as the water absorption index were determined in triplicate according to Anderson [20]. Samples $\left(0.5 \mathrm{~g} ; m_{\text {powder }}\right)$ were dispersed in $19.5 \mathrm{~g}$ of demineralized water, mixed with a vortex mixer (REAX top, Heidolph Instruments GmbH \& Co. KG, Schwabach, Schwabach, Germany) for $1 \mathrm{~min}$ and shaken for $24 \mathrm{~h}$ at $200 \mathrm{~min}^{-1}$ (room temperature) in an universal shaker SM 30C (Edmund Bühler GmbH, Bodelshausen, Germany). To determine the WSI, soluble and insoluble fractions were separated by centrifugation at $4250 \times g$ for $50 \mathrm{~min}$ at $25{ }^{\circ} \mathrm{C}$ (5920R, Eppendorf, Hamburg, Germany). The supernatant was carefully transferred into another tube. Both supernatant and precipitate were weighed, dried for $72 \mathrm{~h}$ at $80^{\circ} \mathrm{C}$ and weighed again. WSI were calculated according to the following equation:

$\mathrm{WSI}=\frac{m_{\text {supernatant, dried }}}{m_{\text {powder }}}$

Centrifugation was not performed to determine WAI. Instead, separation of supernatant and precipitate was due to sedimentation. The supernatant was carefully removed and weighed. The precipitate was dried for $72 \mathrm{~h}$ at $80{ }^{\circ} \mathrm{C}$ and weighed. WAI was calculated according to the following equation:

$\mathrm{WAI}=\frac{m_{\text {preciptate, wet }}-m_{\text {preciptate, dried }}}{m_{\text {preciptate, dried }}}$

\section{Rheological measurements}

Dispersions of thermally or/and mechanically treated samples were prepared by adding $1 \mathrm{~g}$ of treated sample to $10 \mathrm{~g}$ of demineralized water. Dispersions were sealed with paraffin film, stirred for 10 min (Corning 6798-420D, Corning, USA) and stored for $50 \mathrm{~min}$ at room temperature. Rheological properties were measured by using an Anton Paar Rheometer MC 301 (Graz, Austria). A parallel plate geometry with a diameter of $50 \mathrm{~mm}$ was used. First, the linear viscoelastic region (LVE) of the samples was determined with amplitude sweeps. To determine the complex viscosity, the measuring routine starts with a rest of $90 \mathrm{~s}$, before the samples were measured oscillatory with an amplitude of $0.1 \%$ and a frequency of $1 \mathrm{~Hz}$ at $25{ }^{\circ} \mathrm{C}$. Rheological measurements were done in triplicate. 


\section{Results and discussion}

\section{Thermally/mechanically induced changes of apple pomace composition and structure}

\section{Mono- and oligosaccharides, starch}

A recent study on extrusion based compositional and structural alterations of apple pomace reported changes in the contents of free mono- and disaccharides as a result of thermomechanical treatment [3]. Decoupling the thermal treatment from the impact of the mechanical treatment by using CCR suggests that these changes are mainly due to thermal treatment $\left(160{ }^{\circ} \mathrm{C}, \mathrm{D}, \mathrm{E}, \mathrm{F}\right)$ and increased water content $(40 \%, F)$ (Table 2). Differently, both duration of treatment and shear rate (for both treatment temperatures $120{ }^{\circ} \mathrm{C}$ and $160{ }^{\circ} \mathrm{C}$ ) have less of an impact on the contents of mono- and disaccharides. Fructose and, at higher temperatures, sucrose appear to be more susceptible to heat induced degradation as compared to glucose. However, because disaccharides may be cleaved into monosaccharides under the conditions used (for example maltose into glucose, sucrose into glucose and fructose) definite conclusions on the stability of the individual sugars are hard to draw. As discussed in more detail below, reducing sugars such as fructose can also participate in the Maillard reaction.

Starch contents of samples A-F were not statistically different from the starch content of the raw material as presented in Table A1 (Supporting Information).

\section{Dietary fiber contents}

Treating apple pomace at a high temperature of $160{ }^{\circ} \mathrm{C}(\mathrm{D}$, $\mathrm{E}, \mathrm{F})$ resulted in decreasing IDF contents (Table 3). These effects are more pronounced as compared to treatments at $120{ }^{\circ} \mathrm{C}$. However, effects of shear rate and treatment duration on IDF contents were not observed. The most distinct reduction of IDF ( $55 \mathrm{~g} / 100 \mathrm{~g} \mathrm{dm}$ to $42 \mathrm{~g} / 100 \mathrm{~g} \mathrm{dm}$ ) was seen at a treatment temperature of $160{ }^{\circ} \mathrm{C}$ and a water content of $40 \%$ (F) suggesting hydrolytic cleavage of glycosidic linkages under these conditions, resulting in increased solubility of the polymers.

Solubilization of previously water-insoluble polymers is also reflected by increasing SDF contents under thermomechanical treatment. Again, the most notable impact was seen by using treatment temperatures of $160^{\circ} \mathrm{C}(\mathrm{D}, \mathrm{E}, \mathrm{F})$. At this treatment temperature, an effect of a high shear rate $\left(150 \mathrm{~s}^{-1}\right.$,

Table 2 Contents of free mono- and disaccharides $(\mathrm{g} / 100 \mathrm{~g} \mathrm{dm}$, mean value \pm standard deviation, $n=3)$ of apple pomace following treatment in a CCR (closed cavity rheometer)

\begin{tabular}{|c|c|c|c|c|c|c|c|}
\hline & Raw material & A & B & $\mathrm{C}$ & $\mathrm{D}$ & $\mathrm{E}$ & $\mathrm{F}$ \\
\hline Treatment conditions & & $\begin{array}{l}120{ }^{\circ} \mathrm{C} \\
1 \mathrm{~min} \\
150 \mathrm{~s}^{-1} \\
10 \% \text { water }\end{array}$ & $\begin{array}{l}120{ }^{\circ} \mathrm{C} \\
6 \mathrm{~min} \\
150 \mathrm{~s}^{-1} \\
10 \% \text { water }\end{array}$ & $\begin{array}{l}120{ }^{\circ} \mathrm{C} \\
1 \mathrm{~min} \\
0.001 \mathrm{~s}^{-1} \\
10 \% \text { water }\end{array}$ & $\begin{array}{l}160{ }^{\circ} \mathrm{C} \\
1 \mathrm{~min} \\
0.001 \mathrm{~s}^{-1} \\
10 \% \text { water }\end{array}$ & $\begin{array}{l}160{ }^{\circ} \mathrm{C} \\
1 \mathrm{~min} \\
150 \mathrm{~s}^{-1} \\
10 \% \text { water }\end{array}$ & $\begin{array}{l}160{ }^{\circ} \mathrm{C} \\
1 \mathrm{~min} \\
0.001 \mathrm{~s}^{-1} \\
40 \% \text { water }\end{array}$ \\
\hline Glucose $^{\mathrm{a}}$ & $2.8 \pm 0.3^{\mathrm{B}}$ & $3.0 \pm 0.1^{\mathrm{B}}$ & $3.0 \pm 0.1^{\mathrm{B}}$ & $2.9 \pm 0.1^{\mathrm{B}}$ & $3.0 \pm 0.05^{\mathrm{B}}$ & $3.1 \pm 0.1^{\mathrm{B}}$ & $3.5 \pm 0.04^{\mathrm{A}}$ \\
\hline Fructose $^{\mathrm{a}}$ & $8.8 \pm 0.3^{\mathrm{A}}$ & $6.9 \pm 0.1^{\mathrm{B}}$ & $6.6 \pm 0.04^{\mathrm{B}, \mathrm{C}}$ & $6.5 \pm 0.2^{\mathrm{B}, \mathrm{C}}$ & $6.3 \pm 0.1^{\mathrm{C}}$ & $6.6 \pm 0.2^{\mathrm{B}, \mathrm{C}}$ & $6.6 \pm 0.1^{\mathrm{B}, \mathrm{C}}$ \\
\hline Sucrose $\mathrm{a}^{\mathrm{a}}$ & $2.3 \pm 0.4^{\mathrm{B}}$ & $2.9 \pm 0.1^{\mathrm{A}}$ & $2.4 \pm 0.1^{\mathrm{B}, \mathrm{C}}$ & $2.8 \pm 0.1^{\mathrm{A}, \mathrm{C}}$ & $1.6 \pm 0.04^{\mathrm{D}}$ & $1.5 \pm 0.04^{\mathrm{D}}$ & $0.9 \pm 0.03^{\mathrm{E}}$ \\
\hline Maltose $^{\mathrm{a}}$ & $1.4 \pm 0.3^{\mathrm{A}}$ & $\mathrm{b}$ & $0.2 \pm 0.2^{\mathrm{B}}$ & $\mathrm{b}$ & $0.2 \pm 0.02^{\mathrm{B}}$ & $0.4 \pm 0.1^{\mathrm{B}}$ & $\mathrm{b}$ \\
\hline
\end{tabular}

${ }^{\mathrm{a}}$ Mean values within a row that are marked with different letters differ significantly $(p<0.05)$

${ }^{\mathrm{b}}$ Below the limit of quantification

Table 3 Dietary fiber contents ( $\mathrm{g} / 100 \mathrm{~g} \mathrm{dm}$; mean value \pm standard deviation, $n=3$ ) of apple pomace treated in a CCR (closed cavity rheometer)

\begin{tabular}{|c|c|c|c|c|c|c|c|}
\hline & Raw material & A & B & $\mathrm{C}$ & $\mathrm{D}$ & $\mathrm{E}$ & $\mathrm{F}$ \\
\hline Treatment conditions & & $\begin{array}{l}120{ }^{\circ} \mathrm{C} \\
1 \mathrm{~min}^{-1} \\
150 \mathrm{~s}^{-1} \\
10 \% \text { water }\end{array}$ & $\begin{array}{l}120{ }^{\circ} \mathrm{C} \\
6 \mathrm{~min}^{-1} \\
150 \mathrm{~s}^{-1} \\
10 \% \text { water }\end{array}$ & $\begin{array}{l}120{ }^{\circ} \mathrm{C} \\
1 \mathrm{~min} \\
0.001 \mathrm{~s}^{-1} \\
10 \% \text { water }\end{array}$ & $\begin{array}{l}160{ }^{\circ} \mathrm{C} \\
1 \mathrm{~min} \\
0.001 \mathrm{~s}^{-1} \\
10 \% \text { water }\end{array}$ & $\begin{array}{l}160{ }^{\circ} \mathrm{C} \\
1 \mathrm{~min}^{-1} \\
150 \mathrm{~s}^{-1} \\
10 \% \text { water }\end{array}$ & $\begin{array}{l}160{ }^{\circ} \mathrm{C} \\
1 \mathrm{~min} \\
0.001 \mathrm{~s}^{-1} \\
40 \% \text { water }\end{array}$ \\
\hline Total content $\mathrm{t}^{\mathrm{a}}$ & $67.6 \pm 1.7^{\mathrm{C}}$ & $68.4 \pm 1.9^{\text {B.C }}$ & $70.6 \pm 2.7^{\mathrm{B}}$ & $66.7 \pm 1.8^{\mathrm{C}}$ & $67.7 \pm 2.0^{\mathrm{B}, \mathrm{C}}$ & $75.7 \pm 5.3^{\mathrm{A}}$ & $68.3 \pm 2.6^{\mathrm{B}, \mathrm{C}}$ \\
\hline $\mathrm{IDF}^{\mathrm{a}}$ & $54.6 \pm 1.2^{\mathrm{A}}$ & $51.3 \pm 0.2^{\mathrm{A}, \mathrm{B}}$ & $49.8 \pm 0.7^{\mathrm{B}}$ & $49.0 \pm 0.6^{\mathrm{B}}$ & $45.5 \pm 0.5^{\mathrm{C}}$ & $45.6 \pm 0.5^{\mathrm{C}}$ & $42.2 \pm 0.5^{\mathrm{D}}$ \\
\hline $\mathrm{SDF}^{\mathrm{a}}$ & $13.0 \pm 0.5^{\mathrm{E}}$ & $15.1 \pm 1.1^{\mathrm{D}, \mathrm{E}}$ & $17.5 \pm 1.4^{\mathrm{B}, \mathrm{C}, \mathrm{D}}$ & $15.4 \pm 0.9^{\mathrm{C}, \mathrm{D}, \mathrm{E}}$ & $19.3 \pm 0.8^{\mathrm{B}, \mathrm{C}}$ & $26.8 \pm 3.3^{\mathrm{A}}$ & $21.2 \pm 0.6^{\mathrm{B}}$ \\
\hline LMW-SDF ${ }^{\mathrm{a}}$ & - & $2.0 \pm 0.6^{\mathrm{B}}$ & $3.3 \pm 0.6^{\mathrm{A}, \mathrm{B}}$ & $2.3 \pm 0.3^{\mathrm{B}}$ & $2.9 \pm 0.7^{\mathrm{A}, \mathrm{B}}$ & $3.3 \pm 1.5^{\mathrm{A}, \mathrm{B}}$ & $4.9 \pm 1.5^{\mathrm{A}}$ \\
\hline
\end{tabular}

$I D F$ insoluble dietary fiber, SDF: soluble dietary fiber, LMW-SDF: low-molecular weight soluble dietary fiber

${ }^{a}$ Mean values within a row that are marked with different letters differ significantly $(p<0.05)$ 
E) was detected, too, and the content of SDF increased to $26.8 \mathrm{~g} / 100 \mathrm{~g} \mathrm{dm}$. In a previous study on apple pomace [3], the formation of LMW-SDF was already observed for samples that were extruded by applying high thermomechanical stress. The largest amount of LMW-SDF was formed at a treatment temperature of $160{ }^{\circ} \mathrm{C}$ and a water content of $40 \%$ (F). These results support the findings that dietary fiber from apple pomace is susceptible to thermomechanical stress $[3,17]$. However, a detailed chemical interpretation of the changes of IDF, SDF, and LMW-SDF contents is difficult because these changes are most likely the result of a complex interaction: cleavage of glycosidic linkages, degradation of carbohydrate units, and the formation of high-molecular weight Maillard reaction products that are captured as dietary fiber.

\section{Thermally or/and mechanically induced structural changes of dietary fiber polymers}

Molecular weight distribution of soluble dietary fiber polymers Dietary fiber data ("Dietary fiber contents") suggest that maximum structural changes occurred when high temperatures $\left(160^{\circ} \mathrm{C}\right)$ were applied. This is also reflected by the molecular weight distribution of SDF polymers (Fig. 2). The molecular weight distribution of samples that were treated at $120{ }^{\circ} \mathrm{C}(\mathrm{A}, \mathrm{B}, \mathrm{C})$ was only slightly broader as compared to the raw material. Differently, changes were more pro-

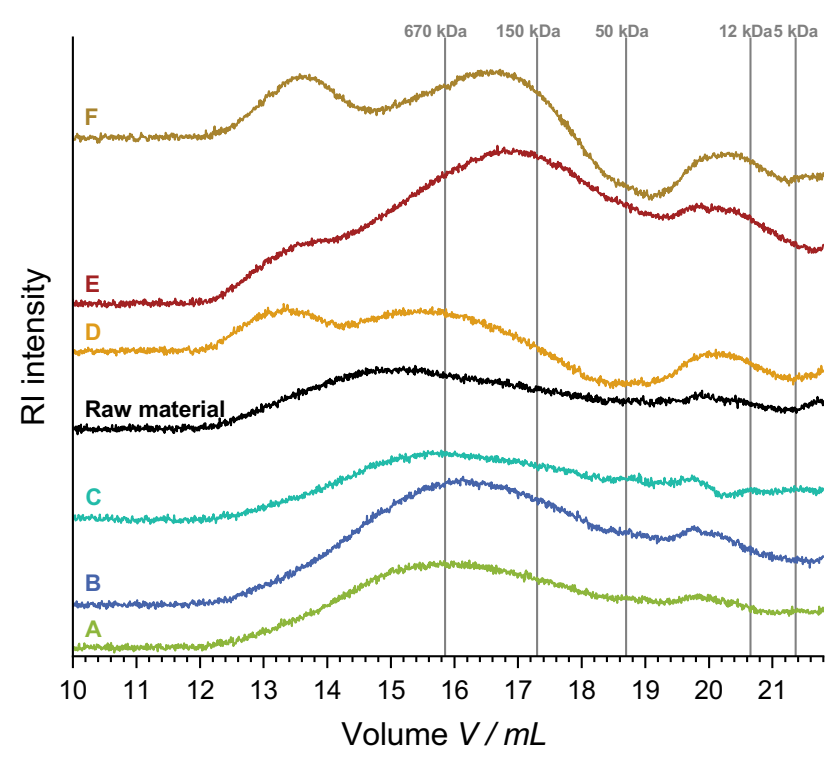

Fig. 2 Molecular weight distribution of soluble dietary fiber polymers of apple pomace that was treated in a closed cavity rheometer. Dextrans of defined molecular weight were used for calibration (grey lines). A: $120{ }^{\circ} \mathrm{C}, 10 \%$ water; $1 \mathrm{~min}, 150 \mathrm{~s}^{-1}$; B: $120^{\circ} \mathrm{C}, 10 \%$ water; $6 \mathrm{~min}, 150 \mathrm{~s}^{-1}$; C: $120{ }^{\circ} \mathrm{C}, 10 \%$ water; $1 \mathrm{~min}, 0.001 \mathrm{~s}^{-1}$; D: $160{ }^{\circ} \mathrm{C}$, $10 \%$ water; $1 \mathrm{~min}, 0.001 \mathrm{~s}^{-1}$, E: $160{ }^{\circ} \mathrm{C}, 10 \%$ water; $1 \mathrm{~min}, 150 \mathrm{~s}^{-1}$; F: $160{ }^{\circ} \mathrm{C}, 40 \%$ water; $1 \mathrm{~min}, 0.001 \mathrm{~s}^{-1}$ nounced for samples that were treated at $160{ }^{\circ} \mathrm{C}(\mathrm{D}, \mathrm{E}, \mathrm{F})$. The molecular weight distribution was clearly broadened and peaks that represent polymers of lower hydrodynamic volume (larger elution volumes) increased in intensity.

Also, an additional peak represented by an elution volume of approximately $13.4 \mathrm{~mL}$ was observed for all samples that were treated at a temperature of $160{ }^{\circ} \mathrm{C}(\mathrm{D}, \mathrm{E}, \mathrm{F})$. This might be due to the formation of melanoidins as end products of the Maillard reaction. Changes in the sugar fraction ("Monoand oligosaccharides, starch") can also be explained by the formation of Maillard products with fructose being generally more reactive than glucose [21].

Monosaccharide composition and glycosidic linkages of dietary fiber poly- and oligosaccharides Analysis of the monosaccharide composition of IDF polysaccharides demonstrate that compositional changes were mostly caused by thermal treatment (Table 4). Whereas changes were more pronounced at $160^{\circ} \mathrm{C}(\mathrm{D}, \mathrm{E}, \mathrm{F})$ as compared to $120^{\circ} \mathrm{C}$ (A, $\mathrm{B}, \mathrm{C})$, variations of the shear rate had no additional effect. Also, different treatment times at $120{ }^{\circ} \mathrm{C}$ (A, B) did not affect the structure differently. The most distinct changes were detected for samples that were treated at an increased water content of $40 \%$ and a treatment temperature of $160{ }^{\circ} \mathrm{C}$ (F). In detail, portions of arabinose and galacturonic acid decreased suggesting thermal instability of the related pectic polysaccharides. This was expected for the arabinans as neutral type I rhamnogalacturonan side-chains because the arabinose units are incorporated in their $\alpha$-furanosidic configuration in the polymers, thereby forming glycosidic linkages that are prone to hydrolysis. Differently, galactose contents are more stable reflecting the stability of galactans as neutral type I rhamnogalacturonan side-chains. A distinct decrease in galactose contents was only found for the sample that was treated at $160{ }^{\circ} \mathrm{C}$ and $40 \%$ water content. These results are consistent with previous studies stating that arabinose and galacturonic acid portions in IDF of apple pomace decrease under thermomechanical stress $[3,17]$. Also, studies on chokeberry pomace that was treated by using a CCR showed that under various thermal effects arabinose and galacturonic acid containing pectic polymers are most prone to degradation [22].

Methylation analysis was carried out only for those IDF samples that were largely affected in their structure by CCR treatment (samples D, E, F) and, for comparison, one sample that was treated at $120{ }^{\circ} \mathrm{C}$ (sample $\mathrm{C}$ ).

Methylation analysis data confirmed that a treatment temperature of $160{ }^{\circ} \mathrm{C}(\mathrm{D}, \mathrm{E}, \mathrm{F})$ results in extensive changes in the structure of IDF polysaccharides (Table 5), whereas changes at a treatment temperature of $120{ }^{\circ} \mathrm{C}$ were minor (note that the methylation analysis protocol used here captures neutral monosaccharides only). Specifically, portions of 1,2,3,5-arabinofuranose and of 1,3,5-linked arabinofuranose 
Table 4 Monosaccharide composition (mol\%) of insoluble dietary fiber of apple pomace that was treated in a closed cavity rheometer (mean value \pm range $/ 2, n=2$ )

\begin{tabular}{llllllll}
\hline & Raw material & $\mathrm{A}$ & $\mathrm{B}$ & $\mathrm{C}$ & $\mathrm{D}$ & $\mathrm{E}$ & $\mathrm{F}$ \\
Treatment & & $120{ }^{\circ} \mathrm{C}$ & $120{ }^{\circ} \mathrm{C}$ & $120{ }^{\circ} \mathrm{C}$ & $160{ }^{\circ} \mathrm{C}$ & $160{ }^{\circ} \mathrm{C}$ & $160{ }^{\circ} \mathrm{C}$ \\
conditions & & $1 \mathrm{~min}$ & $6 \mathrm{~min}$ & $1 \mathrm{~min}$ & $1 \mathrm{~min}$ & $1 \mathrm{~min}$ & $1 \mathrm{~min}$ \\
& & $150 \mathrm{~s}^{-1}$ & $150 \mathrm{~s}^{-1}$ & $0.001 \mathrm{~s}^{-1}$ & $0.001 \mathrm{~s}^{-1}$ & $150 \mathrm{~s}^{-1}$ & $0.001 \mathrm{~s}^{-1}$ \\
& & $10 \%$ water & $10 \%$ water & $10 \%$ water & $10 \%$ water & $10 \%$ water & $40 \%$ water \\
\hline Fuc & $1.0 \pm 0.01$ & $1.2 \pm 0.1$ & $\mathrm{a}$ & $1.2 \pm 0.1$ & $1.4 \pm 0.03$ & $1.4 \pm 0.1$ & $1.2 \pm 0.2$ \\
Rha & $2.3 \pm 0.05$ & $1.7 \pm 0.04$ & $1.8 \pm 0.0002$ & $1.8 \pm 0.04$ & $1.5 \pm 0.02$ & $1.5 \pm 0.04$ & $1.3 \pm 0.1$ \\
Ara & $17.3 \pm 0.8$ & $15.6 \pm 0.04$ & $15.5 \pm 0.2$ & $15.8 \pm 0.2$ & $10.7 \pm 0.03$ & $10.2 \pm 0.02$ & $7.7 \pm 0.1$ \\
Gal & $10.1 \pm 0.2$ & $9.4 \pm 0.1$ & $9.3 \pm 0.1$ & $9.8 \pm 0.3$ & $9.0 \pm 0.2$ & $9.3 \pm 0.5$ & $8.3 \pm 0.1$ \\
Glc & $43.4 \pm 0.3$ & $49.2 \pm 0.4$ & $49.9 \pm 0.2$ & $48.4 \pm 0.5$ & $54.7 \pm 0.3$ & $55.1 \pm 0.3$ & $59.8 \pm 0.1$ \\
Xyl & $11.0 \pm 0.01$ & $10.3 \pm 0.04$ & $10.9 \pm 0.1$ & $10.3 \pm 0.3$ & $11.3 \pm 0.1$ & $11.6 \pm 0.3$ & $12.5 \pm 0.2$ \\
Man & $3.0 \pm 0.2$ & $3.9 \pm 0.1$ & $4.1 \pm 0.04$ & $3.9 \pm 0.01$ & $4.4 \pm 0.1$ & $4.6 \pm 0.2$ & $4.2 \pm 0.6$ \\
GalA & $11.9 \pm 0.8$ & $8.8 \pm 0.1$ & $9.4 \pm 0.1$ & $9.4 \pm 0.2$ & $7.0 \pm 0.1$ & $6.3 \pm 0.2$ & $5.0 \pm 0.3$ \\
GlcA & $\mathrm{a}$ & $\mathrm{a}$ & $\mathrm{a}$ & $\mathrm{a}$ & $\mathrm{a}$ & $\mathrm{a}$ & $\mathrm{a}$
\end{tabular}

Fuc fucose, Rha rhamnose, Ara arabinose, Gal galactose, Glc glucose, Xyl xylose, Man mannose, GalA galacturonic acid; $G l c A$ glucuronic acid

${ }^{a}$ Below the limit of quantification decreased. The original presence of fully branched arabinofuranose units (1,2,3,5-linked) was confirmed in a previous study by using an additional arabinan profiling method to make sure that these units are not the result of undermethylation [3]. The portion of 1,5-linked arabinofuranose units also decreased, however, less pronounced as compared to the branched units. Based on these data, we carefully suggest that under thermal stress branched arabinan units are more susceptible to degradation than linear units.

As already evident from the molecular weight distribution data, any type of thermal and/or mechanical treatment leads to changes in SDF structures and/or its composition. This was also reflected by the monosaccharide compositional data (Table 6).

Most distinct changes were found for sample $\mathrm{F}$ (thermal treatment at $160{ }^{\circ} \mathrm{C}$, water content of $40 \%$ ). These changes were reflected in a decrease in the portion of galacturonic acid and an increase in the portion of galactose, demonstrating the stability of (solubilized) pectic galactans. Although arabinans were potentially solubilized as indicated by IDF compositional data, this is not reflected by the SDF arabinose portions. This might be due to the fact that soluble arabinans are further depolymerized (see below, LMW-SDF) or that the arabinose units are degraded resulting in structures that are not detected here. Methylation analysis data of SDF polysaccharides (Table A2, Supporting Information) did not reveal any further detailed information regarding structural changes under thermal and/or mechanical stress.

Compositional analysis of the LMW-SDF fractions is hard to perform because these fractions were obtained in low amounts only. Also, the precision of the data suffers from the multi-step procedure that is necessary to obtain these samples. Keeping these limitations in mind,
LMW-SDF compositional data demonstrated that strongly thermally stressed apple pomace samples contained LMWSDF of comparably low structural diversity (Table 7). Whereas samples A and B (both treated at $120^{\circ} \mathrm{C}$ ) also contain larger portions of glucose and xylose, the monosaccharide profiles of samples D, E, and F (treated at $160^{\circ} \mathrm{C}$ ) are dominated by arabinose. These data suggest that solubilized arabinans are further cleaved into ethanolsoluble oligo-/polysaccharides. In initial tests to analyze LMW-SDF by using methylation analysis mainly $t$-arabinofuranose and 1,5-linked arabinofuranose were detected supporting this assumption.

\section{Macroscopic structure}

Scanning electron microscopy images (Fig. 3) depict the surface of samples treated at various temperatures and shear rates. The sample treated at $60{ }^{\circ} \mathrm{C}$ without shear had a smooth and closed surface. No changes in the surface structure were observed when samples were treated at $120{ }^{\circ} \mathrm{C}$ without applying shear (C). A further increase in temperature resulted in a rougher surface with small fractions on top (D). The application of shear stress in the $\mathrm{CCR}$ in addition to a high temperature of $160{ }^{\circ} \mathrm{C}(\mathrm{E})$ disrupted the surface of the particles, whereas at $120^{\circ} \mathrm{C}$ (A) shear stress did not affect the surface structure. Instead, the surface appears rather closed or compacted. Thus, a combination of high temperature and shear stress most effectively disrupts the surface structure of the particles. 
Table 5 Glycosidic linkages of insoluble dietary fiber polysaccharides of apple pomace that was treated in a closed cavity rheometer ( $\mathrm{mol} \%$, mean value \pm range $/ 2, \mathrm{n}=2$ )

\begin{tabular}{|c|c|c|c|c|c|}
\hline & Raw material & $\mathrm{C}$ & $\mathrm{D}$ & $\mathrm{E}$ & $\mathrm{F}$ \\
\hline Treatment conditions & & $\begin{array}{l}120{ }^{\circ} \mathrm{C} \\
1 \mathrm{~min} \\
0.001 \mathrm{~s}^{-1} \\
10 \% \text { water }\end{array}$ & $\begin{array}{l}160{ }^{\circ} \mathrm{C} \\
1 \mathrm{~min} \\
0.001 \mathrm{~s}^{-1} \\
10 \% \text { water }\end{array}$ & $\begin{array}{l}160{ }^{\circ} \mathrm{C} \\
1 \mathrm{~min} \\
150 \mathrm{~s}^{-1} \\
10 \% \text { water }\end{array}$ & $\begin{array}{l}160{ }^{\circ} \mathrm{C} \\
1 \mathrm{~min} \\
0.001 \mathrm{~s}^{-1} \\
40 \% \text { water }\end{array}$ \\
\hline 1,2-Rhap & $0.8 \pm 0.1$ & $0.9 \pm 0.02$ & $0.6 \pm 0.01$ & $1.0 \pm 0.4$ & $0.7 \pm 0.01$ \\
\hline 1,2,4-Rhap & $0.4 \pm 0.1$ & $0.6 \pm 0.05$ & $0.7 \pm 0.1$ & $0.8 \pm 0.3$ & $0.5 \pm 0.03$ \\
\hline$\sum \mathrm{Rha}$ & $1.2 \pm 0.2$ & $1.5 \pm 0.1$ & $1.4 \pm 0.1$ & $1.8 \pm 0.6$ & $1.2 \pm 0.04$ \\
\hline t-Araf & $13.5 \pm 2.7$ & $11.5 \pm 0.9$ & $7.2 \pm 0.6$ & $7.0 \pm 0.2$ & $6.4 \pm 1.1$ \\
\hline t-Arap & - & $0.5 \pm 0.01$ & $0.6 \pm 0.1$ & $0.5 \pm 0.03$ & $0.4 \pm 0.01$ \\
\hline 1,2-Araf & - & - & - & $0.3 \pm 0.03$ & - \\
\hline 1,3-Araf & - & $1.7 \pm 0.1$ & $1.2 \pm 0.2$ & $1.5 \pm 0.1$ & $1.1 \pm 0.05$ \\
\hline 1,5-Araf/1,4-Arap & $8.4 \pm 0.04$ & $9.5 \pm 0.1$ & $6.5 \pm 0.4$ & $6.3 \pm 0.3$ & $5.7 \pm 0.3$ \\
\hline 1,2,5-Araf & $1.2 \pm 0.1$ & $1.7 \pm 0.1$ & $1.1 \pm 0.3$ & $0.8 \pm 0.01$ & $0.8 \pm 0.04$ \\
\hline 1,3,5-Araf & $6.6 \pm 0.5$ & $5.2 \pm 0.1$ & $3.4 \pm 0.3$ & $2.8 \pm 0.1$ & $2.9 \pm 0.4$ \\
\hline 1,2,3,5-Araf & $6.6 \pm 0.5$ & $6.9 \pm 0.9$ & $3.1 \pm 0.6$ & $2.7 \pm 0.1$ & $2.3 \pm 0.4$ \\
\hline$\sum$ Ara & $34.0 \pm 3.6$ & $37.1 \pm 2.3$ & $23.0 \pm 2.4$ & $21.9 \pm 0.9$ & $19.6 \pm 2.1$ \\
\hline t-Galp & $2.9 \pm 0.3$ & $3.0 \pm 0.1$ & $3.5 \pm 0.1$ & $3.8 \pm 0.6$ & $3.3 \pm 0.1$ \\
\hline 1,4-Galp & $3.1 \pm 0.1$ & $3.5 \pm 0.03$ & $4.2 \pm 0.1$ & $4.1 \pm 0.2$ & $3.3 \pm 0.5$ \\
\hline 1,6-Galp & $0.3 \pm 0.1$ & $0.4 \pm 0.003$ & $0.5 \pm 0.0002$ & $0.6 \pm 0.2$ & $0.5 \pm 0.01$ \\
\hline$\sum \mathrm{Gal}$ & $6.3 \pm 0.6$ & $6.8 \pm 0.2$ & $8.2 \pm 0.2$ & $8.6 \pm 1.0$ & $7.0 \pm 0.6$ \\
\hline t-Glcp & $1.2 \pm 0.04$ & $0.7 \pm 0.04$ & $1.0 \pm 0.02$ & $1.2 \pm 0.1$ & $1.0 \pm 0.03$ \\
\hline 1,4-Glcp & $35.8 \pm 4.2$ & $30.8 \pm 0.3$ & $36.9 \pm 2.3$ & $38.4 \pm 3.1$ & $41.8 \pm 1.6$ \\
\hline 1,4,6-Glcp & $5.7 \pm 1.4$ & $7.7 \pm 0.1$ & $9.4 \pm 0.2$ & $8.6 \pm 0.4$ & $9.4 \pm 0.2$ \\
\hline$\sum \mathrm{Glc}$ & $42.7 \pm 1.4$ & $39.3 \pm 0.5$ & $47.3 \pm 2.5$ & $48.3 \pm 3.6$ & $52.2 \pm 1.9$ \\
\hline t-Manp & $2.9 \pm 0.8$ & $0.2 \pm 0.01$ & $0.2 \pm 0.01$ & $0.3 \pm 0.1$ & $0.2 \pm 0.02$ \\
\hline 1,4-Manp & $0.5 \pm 0.2$ & $2.8 \pm 0.1$ & $3.6 \pm 0.2$ & $4.3 \pm 1.3$ & $3.6 \pm 0.2$ \\
\hline 1,4,6-Manp & $0.5 \pm 0.2$ & $0.5 \pm 0.01$ & $0.6 \pm 0.0002$ & $0.8 \pm 0.3$ & $0.6 \pm 0.05$ \\
\hline$\sum$ Man & $3.4 \pm 1.0$ & $3.5 \pm 0.1$ & $4.5 \pm 0.2$ & $5.3 \pm 1.7$ & $4.4 \pm 0.3$ \\
\hline t-Xylp & $7.8 \pm 0.6$ & $7.4 \pm 0.1$ & $9.5 \pm 0.2$ & $8.5 \pm 0.6$ & $9.3 \pm 0.6$ \\
\hline $1,2-X_{1}{ }^{a}$ & $2.7 \pm 0.5$ & $2.5 \pm 0.1$ & $3.5 \pm 0.01$ & $3.2 \pm 0.04$ & $3.6 \pm 0.03$ \\
\hline $1,4-X y l p^{a}$ & $1.9 \pm 0.2$ & $1.9 \pm 0.1$ & $2.7 \pm 0.3$ & $2.5 \pm 0.3$ & $2.5 \pm 0.1$ \\
\hline$\sum \mathrm{Xyl}$ & $12.4 \pm 1.4$ & $11.8 \pm 0.3$ & $15.7 \pm 0.5$ & $14.2 \pm 0.9$ & $15.3 \pm 0.7$ \\
\hline
\end{tabular}

$t$ terminal, $p$ pyranose, $f$ furanose, Rha rhamnose, Ara arabinose, Gal galactose, Glc glucose, Man mannose, $\mathrm{Xyl}$ xylose

${ }^{a}$ Coeluting, determined from the area ratio of the characteristic fragment ion peaks. 1,2-Xylp: $\mathrm{m} / \mathrm{z} 117,1,4-$ Xylp: m/z 118

\section{Thermally/mechanically induced changes of the functional properties of apple pomace}

\section{Water solubility index (WSI) and water absorption index (WAI)}

Figure 4 shows the influence of treatment temperature on the WSI of apple pomace using water contents of 10,20 , or $40 \%$ $(w / w)$, respectively, during the treatment. The samples were treated for 1 min without shear $\left(\dot{\gamma}=0.001 \mathrm{~s}^{-1}\right)$.

At a treatment temperature of $60{ }^{\circ} \mathrm{C}$, WSI were similar to that of the raw material $(25.2 \%)$. Increasing the treatment temperature initially reduces WSI with a minimum being reached at a treatment temperature of $120^{\circ} \mathrm{C}$ for water contents of $10 \%$ and $20 \%$. Differently, the minimum WSI was already reached at $90{ }^{\circ} \mathrm{C}$, when a water content of $40 \%$ was used during the treatment.

A further increase in treatment temperature $\left(160{ }^{\circ} \mathrm{C}\right)$ resulted in higher WSI than determined for the raw material. At $180{ }^{\circ} \mathrm{C}$, which is the max. temperature reaches at extrusion processing, WSI reached the overall maximum of $39.3 \%$ when a water content of $40 \%$ was applied.

Decreasing WSI at $120{ }^{\circ} \mathrm{C}$ cannot easily be explained by the shift of the dietary fiber composition ("Dietary fiber contents", Table 3). However, increasing WSI at high treatment temperatures of $160^{\circ} \mathrm{C}$ is in accordance with increased SDF and decreased IDF contents. Generally, however, it needs to be considered that other compounds besides dietary fiber, 
Table 6 Monosaccharide composition ( $\mathrm{mol} \%)$ of soluble dietary fiber polysaccharides of apple pomace that was treated in a closed cavity rheometer (mean value \pm range/ $2, \mathrm{n}=2$ )
Table 7 Monosaccharide composition (mol\%) of lowmolecular weight soluble dietary fiber of apple pomace that was treated in a closed cavity rheometer (mean value \pm standard deviation, $n=3$ )

\begin{tabular}{|c|c|c|c|c|c|c|c|}
\hline & Raw material & A & B & $\mathrm{C}$ & $\mathrm{D}$ & E & $\mathrm{F}$ \\
\hline $\begin{array}{l}\text { Treatment } \\
\text { conditions }\end{array}$ & & $\begin{array}{l}120{ }^{\circ} \mathrm{C} \\
1 \mathrm{~min}^{-1} \\
150 \mathrm{~s}^{-1} \\
10 \% \text { water }\end{array}$ & $\begin{array}{l}120{ }^{\circ} \mathrm{C} \\
6 \mathrm{~min} \\
150 \mathrm{~s}^{-1} \\
10 \% \text { water }\end{array}$ & $\begin{array}{l}120{ }^{\circ} \mathrm{C} \\
1 \mathrm{~min} \\
0.001 \mathrm{~s}^{-1} \\
10 \% \text { water }\end{array}$ & $\begin{array}{l}160{ }^{\circ} \mathrm{C} \\
1 \mathrm{~min} \\
0.001 \mathrm{~s}^{-1} \\
10 \% \text { water }\end{array}$ & $\begin{array}{l}160{ }^{\circ} \mathrm{C} \\
1 \mathrm{~min} \\
150 \mathrm{~s}^{-1} \\
10 \% \text { water }\end{array}$ & $\begin{array}{l}160{ }^{\circ} \mathrm{C} \\
1 \mathrm{~min} \\
0.001 \mathrm{~s}^{-1} \\
40 \% \text { water }\end{array}$ \\
\hline Fuc & a & $\mathrm{a}$ & $\mathrm{a}$ & $\mathrm{a}$ & a & $\mathrm{a}$ & $\mathrm{a}$ \\
\hline Rha & $4.4 \pm 0.2$ & $3.2 \pm 0.01$ & $3.5 \pm 0.1$ & $4.0 \pm 0.1$ & $4.2 \pm 0.1$ & $4.7 \pm 0.03$ & $6.1 \pm 1.0$ \\
\hline Ara & $42.0 \pm 0.2$ & $44.7 \pm 0.6$ & $49.3 \pm 0.6$ & $46.1 \pm 0.2$ & $46.1 \pm 0.3$ & $47.5 \pm 1.7$ & $42.8 \pm 2.6$ \\
\hline Gal & $8.8 \pm 0.9$ & $9.4 \pm 0.1$ & $9.5 \pm 0.6$ & $9.7 \pm 0.3$ & $12.6 \pm 0.1$ & $12.7 \pm 0.4$ & $19.1 \pm 4.0$ \\
\hline Glc & $4.7 \pm 1.4$ & $3.2 \pm 0.9$ & $2.3 \pm 0.2$ & $3.8 \pm 1.4$ & $2.1 \pm 0.1$ & $2.2 \pm 0.1$ & $2.8 \pm 0.8$ \\
\hline Xyl & $1.7 \pm 0.3$ & $2.4 \pm 0.5$ & $1.7 \pm 0.04$ & $2.4 \pm 0.4$ & $2.5 \pm 0.01$ & $2.8 \pm 0.02$ & $3.9 \pm 0.8$ \\
\hline Man & $4.7 \pm 0.7$ & $3.8 \pm 0.1$ & $3.1 \pm 0.01$ & $4.1 \pm 0.01$ & $2.4 \pm 0.01$ & $2.4 \pm 0.04$ & $2.2 \pm 0.3$ \\
\hline GalA & $32.9 \pm 0.4$ & $33.4 \pm 0.8$ & $30.7 \pm 1.1$ & $29.9 \pm 2.5$ & $30.2 \pm 0.4$ & $27.7 \pm 2.0$ & $23.0 \pm 4.0$ \\
\hline GlcA & $0.8 \pm 0.05$ & $\mathrm{a}$ & $\mathrm{a}$ & $\mathrm{a}$ & $\mathrm{a}$ & a & $\mathrm{a}$ \\
\hline
\end{tabular}

Fuc fucose, Rha rhamnose, Ara arabinose, Gal galactose, Glc glucose, Xyl xylose, Man mannose, GalA galacturonic acid; GlcA glucuronic acid

${ }^{a}$ Below the limit of quantification

\begin{tabular}{lllllll}
\hline & $\mathrm{A}$ & $\mathrm{B}$ & $\mathrm{C}$ & $\mathrm{D}$ & $\mathrm{E}$ & $\mathrm{F}$ \\
Treatment & $120{ }^{\circ} \mathrm{C}$ & $120{ }^{\circ} \mathrm{C}$ & $120{ }^{\circ} \mathrm{C}$ & $160{ }^{\circ} \mathrm{C}$ & $160{ }^{\circ} \mathrm{C}$ & $160{ }^{\circ} \mathrm{C}$ \\
conditions & $1 \mathrm{~min}^{-1}$ & $6 \mathrm{~min}^{-1}$ & $1 \mathrm{~min}$ & $1 \mathrm{~min}$ & $1 \mathrm{~min}$ & $1 \mathrm{~min}$ \\
& $150 \mathrm{~s}^{-1}$ & $150 \mathrm{~s}^{-1}$ & $0.001 \mathrm{~s}^{-1}$ & $0.001 \mathrm{~s}^{-1}$ & $150 \mathrm{~s}^{-1}$ & $0.001 \mathrm{~s}^{-1}$ \\
& $10 \%$ water & $10 \%$ water & $10 \%$ water & $10 \%$ water & $10 \%$ water & $40 \%$ water \\
\hline Rha & $\mathrm{a}$ & $\mathrm{a}$ & $\mathrm{a}$ & $0.3 \pm 0.5$ & $\mathrm{a}$ & $\mathrm{a}$ \\
Ara & $40.7 \pm 12.0$ & $33.7 \pm 11.8$ & $86.5 \pm 7.6$ & $90.3 \pm 1.1$ & $91.5 \pm 3.7$ & $93.7 \pm 0.7$ \\
Gal & $4.3 \pm 0.9$ & $5.2 \pm 0.5$ & $\mathrm{a}$ & $\mathrm{a}$ & $\mathrm{a}$ & $1.5 \pm 0.2$ \\
Glc & $33.4 \pm 7.7$ & $40.1 \pm 9.8$ & $11.7 \pm 9.0$ & $5.8 \pm 1.2$ & $6.3 \pm 3.5$ & $3.1 \pm 0.8$ \\
Xyl & $16.6 \pm 3.7$ & $17.4 \pm 1.3$ & $\mathrm{a}$ & $1.6 \pm 1.0$ & $\mathrm{a}$ & $\mathrm{a}$ \\
Man & $2.5 \pm 0.5$ & $2.0 \pm 0.3$ & $1.8 \pm 1.6$ & $2.0 \pm 0.6$ & $2.2 \pm 0.4$ & $1.6 \pm 0.1$ \\
GalA & $2.5 \pm 1.5$ & $1.5 \pm 0.2$ & $\mathrm{a}$ & $\mathrm{a}$ & $\mathrm{a}$ & $\mathrm{a}$ \\
\hline
\end{tabular}

Rha rhamnose, Ara arabinose, Gal galactose, Glc glucose, Xyl xylose, Man mannose, GalA galacturonic acid

${ }^{a}$ Below the limit of quantification e.g., protein, starch, and low-molecular-weight sugars, affect WSI, too.

In extrusion processing, the material is exposed not only to thermal, but also to mechanical stress. Therefore, the impact of mechanical stress at various treatment temperatures is investigated in the following. Figure 5 shows the WSI as a function of shear rate at various treatment temperatures for a water content of $10 \%$. It is apparent that the shear rate had an impact on the WSI of apple pomace at all temperatures. For moderate treatment temperatures of $60^{\circ} \mathrm{C}$, the WSI value increased from 25.8 to $28.0 \%$, whereas at high treatment temperatures of $180{ }^{\circ} \mathrm{C}$, the WSI values increased from 32.8 to $36.2 \%$. Also, slight increases of WSI with increasing shear rate were observed at $120{ }^{\circ} \mathrm{C}(20.5-21.5 \%)$, which is still lower than the WSI of the raw material. These data suggest that shear stress contributes to the deconstruction of cell walls, being in alignment with the images of the particle surfaces (Fig. 3). At a treatment temperature of $160{ }^{\circ} \mathrm{C}$, the SDF content ("Dietary fiber contents", Table 3) increased with increasing shear rates $\left(0.001 \mathrm{~s}^{-1}\right.$, D vs. $\left.150 \mathrm{~s}^{-1}, \mathrm{E}\right)$. However, no effect of the shear rate on SDF contents was observed at a treatment temperature of $120^{\circ} \mathrm{C}$ (C vs A).

Comparing the results with data from extrusion processing [3], similar trends were observed. Considering a water content of $42 \%$ and a material temperature within a range of $112-145^{\circ} \mathrm{C}$ during extrusion processing, WSI also decreased under the value of the raw material. Differently, samples that were extruded at a material temperature of approx. $160{ }^{\circ} \mathrm{C}$ and water contents of 10 or $20 \%$ showed significantly higher WSI than the raw material, too [3]. The maximum shear rates in extrusion processing are much higher than in the CCR [8]. However, the maximum shear rates act on the molecules over a short residence time 


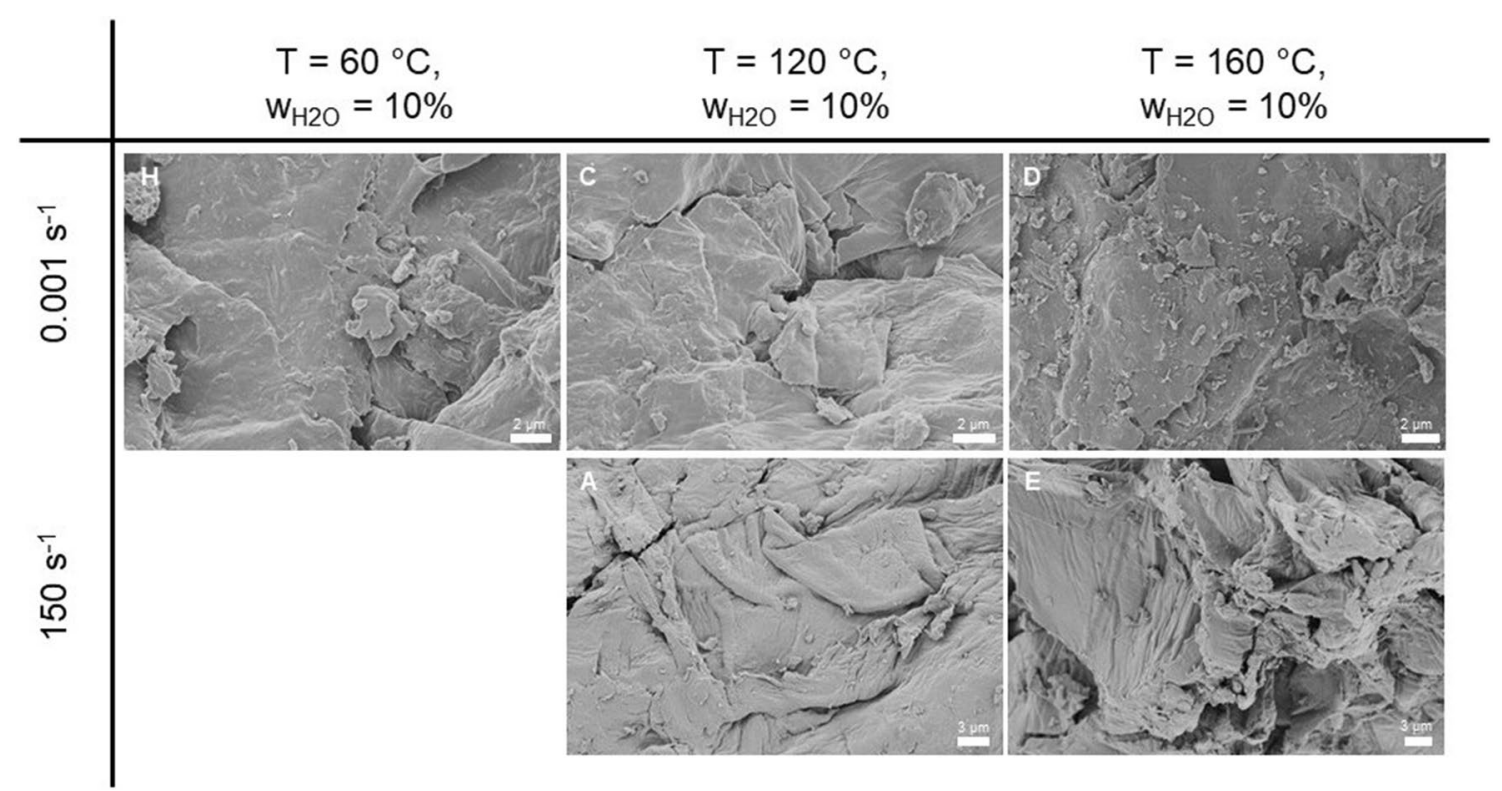

Fig. 3 Scanning electron microscopy images of surfaces of treated apple pomace particles. A: $120{ }^{\circ} \mathrm{C}, 10 \%$ water; $1 \mathrm{~min}, 150 \mathrm{~s}^{-1}$; $\mathrm{C}: 120{ }^{\circ} \mathrm{C}$, $10 \%$ water; $1 \mathrm{~min}, 0.001 \mathrm{~s}^{-1}$; D: $160{ }^{\circ} \mathrm{C}, 10 \%$ water; $1 \mathrm{~min}, 0.001 \mathrm{~s}^{-1}$, E: $60^{\circ} \mathrm{C}, 10 \%$ water; $1 \mathrm{~min}, 150 \mathrm{~s}^{-1} ; \mathrm{H}: 60{ }^{\circ} \mathrm{C}, 10 \%$ water; 1 min

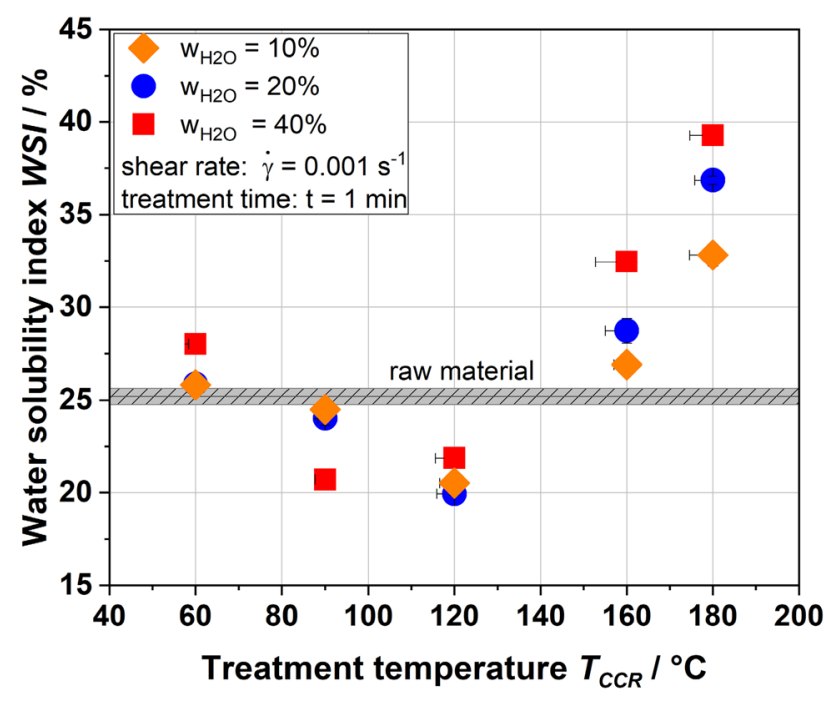

Fig. 4 Change of water solubility indices (WSI) after thermal treatment $\left(\mathrm{T}_{\mathrm{CCR}}\right)$ of apple pomace in the Closed Cavity Rheometer for various water contents of 10,20 , and $40 \%$ and without shear $\left(0.001 \mathrm{~s}^{-1}\right)$; treatment time: $1 \mathrm{~min}$

(milliseconds) and at the tips of the screws only [23]. In average, the applied shear rates are in the same range [24].

In Fig. 6, WSI as a function of treatment time at treatment temperatures of 120 and $160{ }^{\circ} \mathrm{C}$ for a water content of $10 \%$ and a shear rate of $150 \mathrm{~s}^{-1}$ are depicted. For both treatment temperatures, longer treatment times of 3,6 , and $10 \mathrm{~min}$ resulted in an apparent increase in WSI values by $\sim 4$ and $\sim 9 \%$ for 120 and $160{ }^{\circ} \mathrm{C}$. Average residence

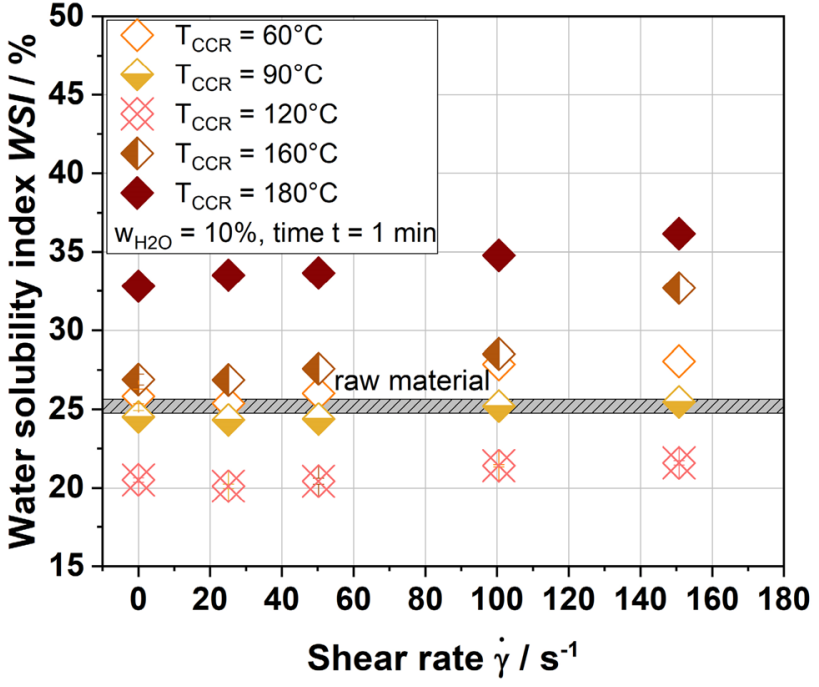

Fig. 5 Change of water solubility indices (WSI) after thermal and thermomechanical treatment $(\dot{\gamma})$ of apple pomace at various temperatures $\mathrm{T}_{\mathrm{CCR}}$ in the $\mathrm{CCR}$ at a water content of $10 \%$; treatment time: $1 \mathrm{~min}$

times in extrusion processing vary between $30 \mathrm{~s}$ and 2.5 min depending on process parameters and extruder type, respectively [25]. Thus, no comparison regarding the WSI values for longer treatment times can be provided.

For applications in food systems, the amount of water that is absorbed and bound by the sample is important to know. Thus, water absorption indices (WAI) are shown in 


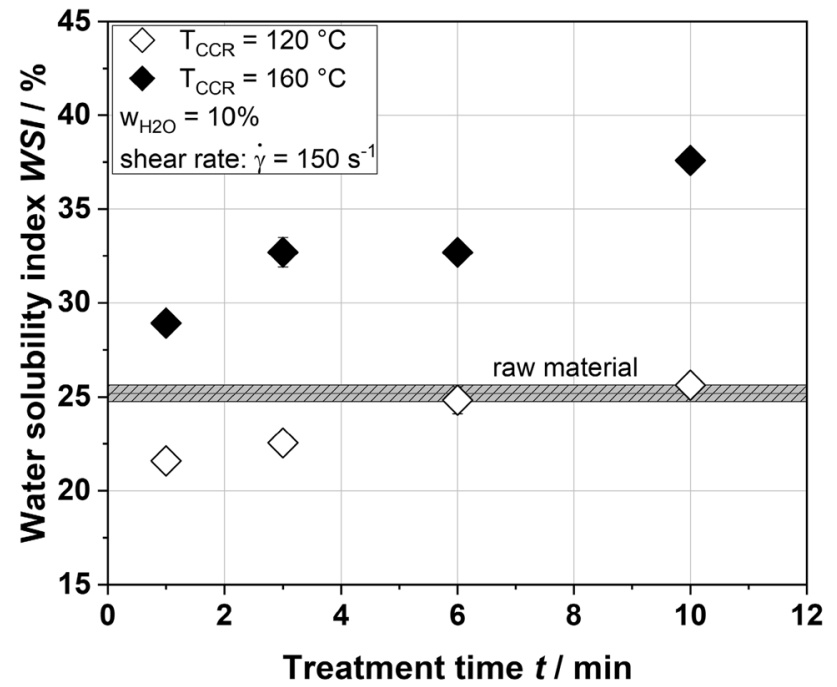

Fig. 6 Change of water solubility indices (WSI) after thermomechanical treatment of apple pomace at various treatment times in the Closed Cavity Rheometer at treatment temperatures of 120 and $160{ }^{\circ} \mathrm{C}$, a water content of $10 \%$ and a high shear rate of $150 \mathrm{~s}^{-1}$

Fig. 7A for various treatment temperatures at water contents of 10, 20 and $40 \%$, without application of shear.

The WAI for the raw material was $7.3 \pm 0.3$. Samples thermally treated at $60{ }^{\circ} \mathrm{C}$ and $90{ }^{\circ} \mathrm{C}$ and at a water content of $40 \%$ and $20 \%$ had slightly higher WAI. An apparent drop in WAI was observed at a treatment temperature of $120^{\circ} \mathrm{C}$ for all water contents, being in accordance with WSI data. At higher treatment temperatures, WAI increased and were slightly higher than the WAI of the raw material. Figure 3 indicates that this change in the WAI might be related to changes in the macroscopic structure, such as surface and porosity. On SEM image (Fig. 3A) of the sample treated with high shear stress at $120^{\circ} \mathrm{C}$, the surface seemed denser or slightly compressed. A denser surface can explain the decrease in WAI at $120^{\circ} \mathrm{C}$.

As shown in Fig. 7B, an increase in shear rates resulted in higher WAI values at all treatment temperatures for water contents of $10 \%$ and $40 \%$, except at a treatment temperature of $120{ }^{\circ} \mathrm{C}$. As discussed before, the results suggest that defined shear treatment in CCR partially destroys the cell wall, and more water can be absorbed and bound by the cell wall polymers. These findings are consistent with data reported by Redgwell et al., who reported an increase in water retention capacity after shear treatment of apple pomace, too. However, the effect was less pronounced [26]. Chemical analyses ("Thermally/mechanically induced changes of apple pomace composition and structure") showed that arabinan side-chains and pectic polymers that contain galacturonic acid are mostly affected by increasing thermomechanical treatment, potentially resulting in loosened cell wall structures, which might explain higher WAI.

WAI as a function of time is depicted in Fig. 8. A treatment time of $3 \mathrm{~min}$ resulted in a large increase of WAI for both treatment temperatures of $120^{\circ} \mathrm{C}$ and $160^{\circ} \mathrm{C}$. The maximum WAI at a treatment temperature of $160^{\circ} \mathrm{C}$ was reached for treatment times between 3 and $6 \mathrm{~min}$, whereas the maximum was between 6 and 10 min when a treatment temperature of $120^{\circ} \mathrm{C}$ was applied. Higher temperatures can accelerate the degradation of the cell wall, potentially explaining that the maximum WAI was reached at shorter times when $160^{\circ} \mathrm{C}$ was applied. Since only treatment times of 1,3 , and 6 min were investigated, it can be assumed that the maximum value was not captured and is located between 1 and 6 min.
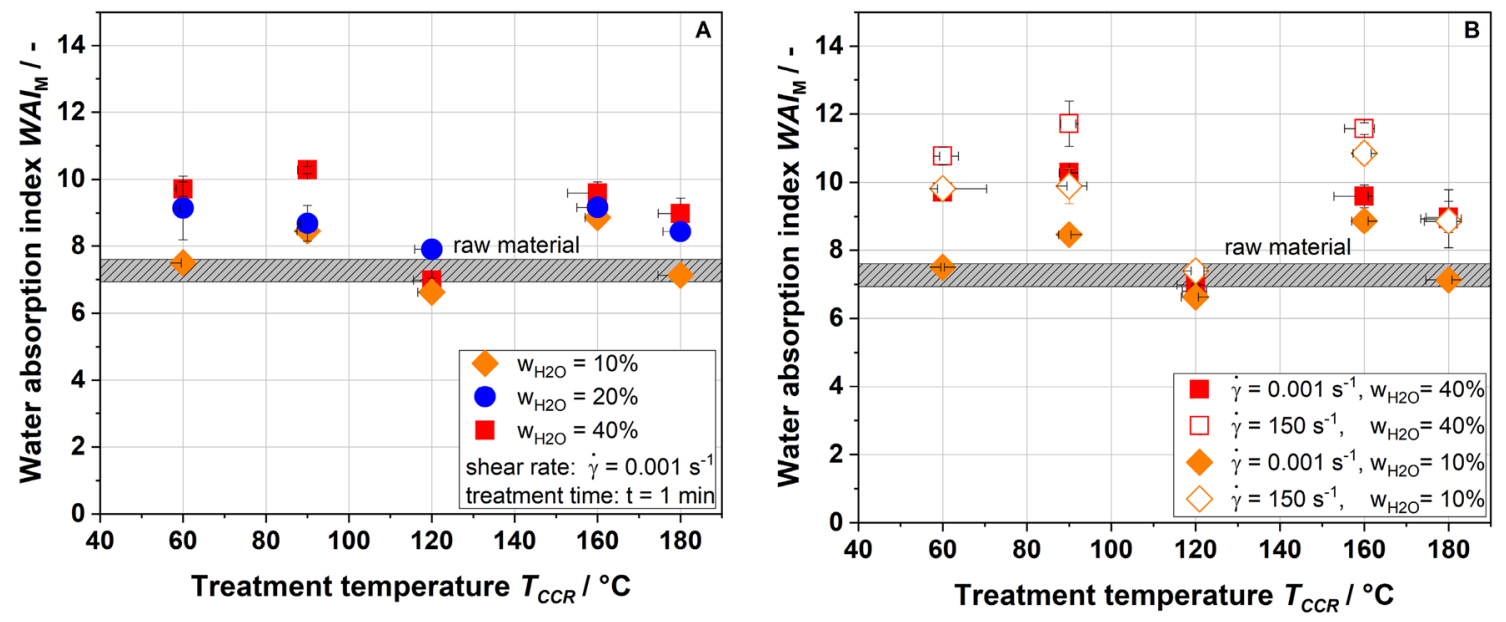

Fig. 7 Water absorption index (WAI) over treatment temperature $\mathrm{T}_{\mathrm{CCR}}(\mathbf{A})$ without shear $\left(0.001 \mathrm{~s}^{-1}\right)$ for various water contents of 10 , 20, and $40 \%$ and $(\mathbf{B})$ without shear $\left(0.001 \mathrm{~s}^{-1}\right.$, open symbols) and with shear $\left(150 \mathrm{~s}^{-1}\right.$, closed symbols) for water contents of 10 and $40 \%$ 


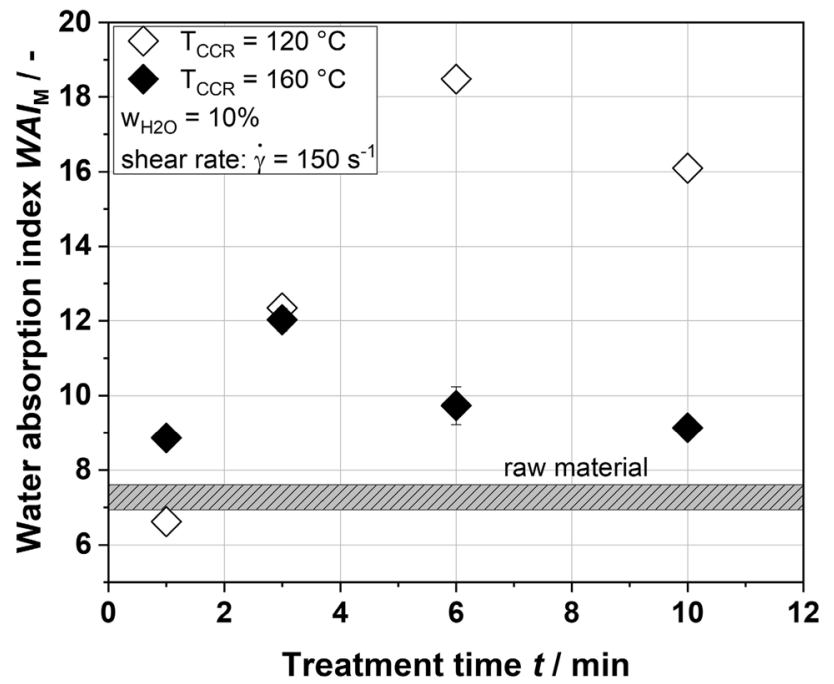

Fig. 8 Water absorption index (WAI) over treatment time for a water content of $10 \%$ at treatment temperatures of $120{ }^{\circ} \mathrm{C}$ and $160{ }^{\circ} \mathrm{C}$ and a shear rate of $150 \mathrm{~s}^{-1}$

\section{Viscosity of dispersions}

After a thermal and/or thermomechanical treatment of apple pomace, the complex viscosity of dispersions made from treated samples and water were measured (Fig. 9).

Treatment temperature had an influence on the complex viscosity of dispersions made from treated apple pomace. For treatment temperatures of $60^{\circ} \mathrm{C}$ and $90{ }^{\circ} \mathrm{C}$, the complex viscosity of the samples treated at a water content of $40 \%$ (Fig. 9A) and 10\% (Fig. 9B) was higher (max. 394 Pas) than the complex viscosity of the raw material (4.6 Pas). However, similar to WSI (Fig. 4) and WAI (Fig. 7), the complex viscosity of dispersions made from samples that were treated at $120{ }^{\circ} \mathrm{C}$ differs from other samples. Here, the complex viscosity was lower than the complex viscosity of the raw material. Possible explanation might be the formation of more compact cell wall structures at this temperature, which can get destructed at higher treatment temperatures (Fig. 3). The correlation between disruption of the cell wall, water absorption, and viscosity of the dispersions was previously reported for extruded apple pomace $[3,17]$.

By increasing the treatment temperature to $160{ }^{\circ} \mathrm{C}$, apple pomace was obtained that creates higher viscosities than the raw material. However, a further increase in treatment temperature was demonstrated to be detrimental with regard to viscosity; especially samples that were treated at $180{ }^{\circ} \mathrm{C}$ and a water content of $10 \%$ showed very low viscosities for both shear rates. This indicates that a maximum treatment temperature was exceeded to obtain apple pomace that is able to form highly viscous dispersions. Finally, the applied shear rate also affects the viscosity forming properties of the obtained processed apple pomace. As a general trend, application of higher shear rates appear to result in samples that showed higher complex viscosities.

\section{Conclusion}

The results showed the individual effects of temperature and shear on the chemical and macroscopic structure as well as functional properties of apple pomace. In addition to temperature, the application of shear led to a decrease in IDF and an increase in SDF as well as LMW-SDF. Mainly pectic polysaccharides are susceptible to thermal and mechanical treatment. In IDF fractions, portions of arabinose and galacturonic acid decreased, and in SDF fractions, a decrease of the portion of galacturonic acid was most distinct. Furthermore,
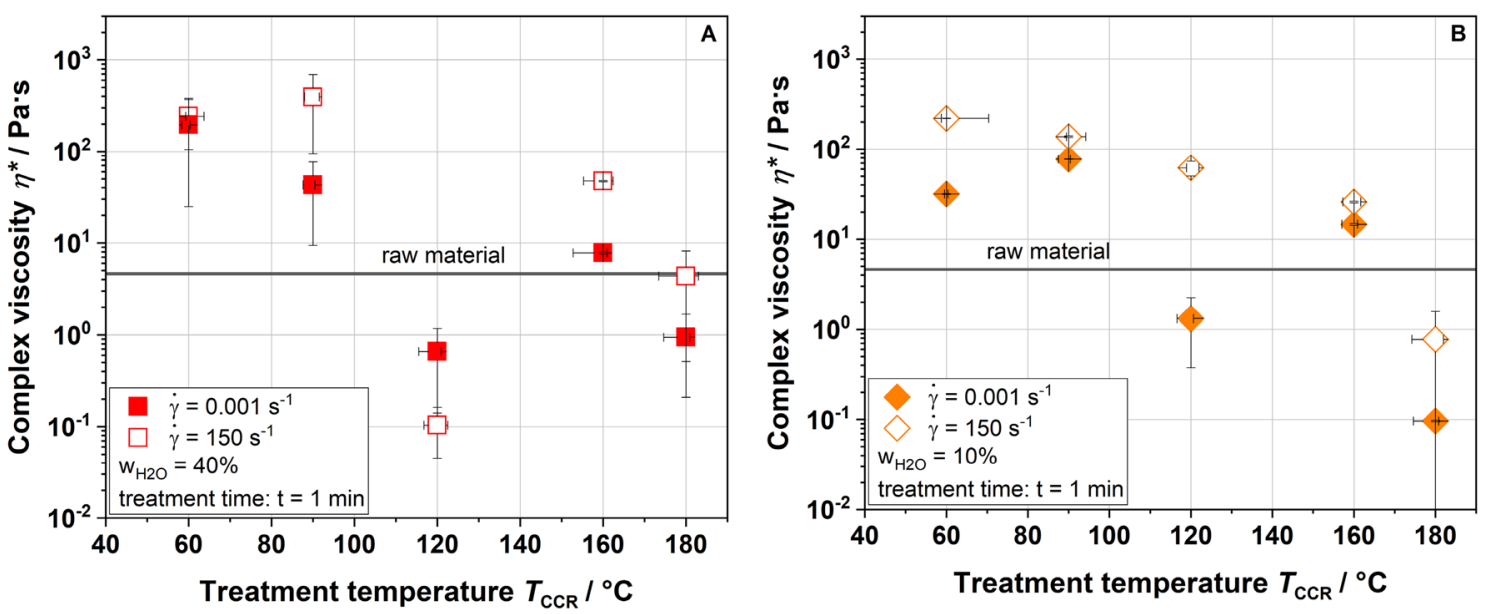

Fig. 9 Effect of treatment temperature and shear rate $\left(0.001\right.$ and $\left.150 \mathrm{~s}^{-1}\right)$ on the complex viscosity of apple pomace. A: water content during treatment $40 \%$; B: water content during treatment $10 \%$ 
the surface was altered by an increase in temperature and shear. All functional properties (WSI, WAI, and viscosity of dispersions) decreased for $120^{\circ} \mathrm{C}$ and increased at $T>\sim 135{ }^{\circ} \mathrm{C}$ compared to the raw material. In the range investigated, in comparison to shear, the temperature showed a more pronounced effect on the functional changes. Nevertheless, it must be noted that the shear rates applied during extrusion are 10 times higher than the values applied by CCR.

The identification of the impact of temperature and shear on the modification of structure and functional properties allows modifying by-products according to specific needs, which is in line with the objective of upcycling food byproducts in order to reuse them.

Supplementary Information The online version contains supplementary material available at https://doi.org/10.1007/s00217-021-03776-0.

Acknowledgements The authors would like to express their thanks to Andrea Butterbrodt, Felix Ellwanger, Kathrin Dyhr, Bettina Bastius for supporting sample analyses, and Herbafood Ingredients $\mathrm{GmbH}$ for providing the apple pomace.

Author contributions VS: data curation, investigation, methodology, project administration, visualization, writing-original draft, writingreview and editing original draft. AT: data curation, methodology, investigation, visualization, writing - original draft. JK: project administration, methodology, supervision, writing-review and editing. MB: conceptualization, funding acquisition, project administration, resources, supervision, writing - review and editing. HPK: funding acquisition, resources, writing - review and editing. MAZ: conceptualization, funding acquisition, project administration, resources, supervision, writing — review and editing.

Funding Open Access funding enabled and organized by Projekt DEAL. The IGF research project (20518N) of the FEI was supported via $\mathrm{AiF}$ within the program for promoting the Industrial Collective Research (IGF) of the German Ministry of Economics and Energy (BMWi), bases on a resolution of German Parliament.

\section{Declarations}

Conflict of interest The authors have no conflicts of interest to declare that are relevant to the content of this article.

Compliance with ethics requirements There was no research involving human participants and/or animals.

Open Access This article is licensed under a Creative Commons Attribution 4.0 International License, which permits use, sharing, adaptation, distribution and reproduction in any medium or format, as long as you give appropriate credit to the original author(s) and the source, provide a link to the Creative Commons licence, and indicate if changes were made. The images or other third party material in this article are included in the article's Creative Commons licence, unless indicated otherwise in a credit line to the material. If material is not included in the article's Creative Commons licence and your intended use is not permitted by statutory regulation or exceeds the permitted use, you will need to obtain permission directly from the copyright holder. To view a copy of this licence, visit http://creativecommons.org/licenses/by/4.0/.

\section{References}

1. Elleuch M, Bedigian D, Roiseux O et al (2011) Dietary fibre and fibre-rich by-products of food processing: characterisation, technological functionality and commercial applications: a review. Food Chem 124:411-421. https://doi.org/10.1016/j.foodchem. 2010.06.077

2. Offiah V, Kontogiorgos V, Falade KO (2019) Extrusion processing of raw food materials and by-products: a review. Crit Rev Food Sci Nutr 59:2979-2998. https://doi.org/10.1080/10408398.2018. 1480007

3. Schmid V, Trabert A, Schäfer J et al (2020) Modification of apple pomace by extrusion processing: Studies on the composition, polymer structures, and functional properties. Foods 9:1385

4. Kennedy M, List D, Lu Y et al (1999) Apple pomace and produicts derived from apple pomace: uses, composition and analysis. In: Linskens HF, Jackson JF (eds) Analysis of plant waste materials. Molecular methods of plant analysis. Springer-Verlag, Berlin, pp 75-120

5. Figuerola F, Hurtado ML, Estévez AM et al (2005) Fibre concentrates from apple pomace and citrus peel as potential fibre sources for food enrichment. Food Chem 91:395-401. https://doi.org/10. 1016/j.foodchem.2004.04.036

6. Lu Y, Foo LY (1997) Identification and quantification of major polyphenols in apple pomace. Food Chem 59:187-194. https:// doi.org/10.1016/S0308-8146(96)00287-7

7. Renard CMGC, Thibault J-F (1991) Composition and physicochemical properties of apple fibres from fresh fruits and industrial products. Lebensmittel-Wissenschaft und-Technologie 24:523-527

8. Emin MA, Schuchmann HP (2013) Analysis of the dispersive mixing efficiency in a twin-screw extrusion processing of starch based matrix. J Food Eng 115:132-143. https://doi.org/10.1016/j. jfoodeng.2012.10.008

9. Hwang J-K (1998) Solubilization of Apple Pomace by Extrusion. J Food Process Preserv 22:477-491

10. Reis SF, Rai DK, Abu-Ghannam N (2014) Apple pomace as a potential ingredient for the development of new functional foods. Int J Food Sci Technol 49:1743-1750. https://doi.org/10.1111/ijfs. 12477

11. Emin MA, Schuchmann HP (2017) A mechanistic approach to analyze extrusion processing of biopolymers by numerical, rheological, and optical methods. Trends Food Sci Technol 60:88-95. https://doi.org/10.1016/j.tifs.2016.10.003

12. Wefers D, Gmeiner BM, Tyl CE et al (2015) Characterization of diferuloylated pectic polysaccharides from quinoa (Chenopodium quinoa WILLD.). Phytochemistry 116:320-328

13. Prosky L, Asp NG, Furda I et al (1985) Determination of total dietary fiber in foods and food products: collaborative study. $\mathrm{J}$ AOAC Int 68:677-679

14. McCleary BV, DeVries JW, Rader JI et al (2010) Determination of total dietary fiber (CODEX definition) by enzymatic-gravimetric method and liquid chromatography: Collaborative study. J AOAC Int 1:221-233

15. Urbat F, Müller P, Hildebrand A et al (2019) Comparison and optimization of different protein nitrogen quantitation and residual protein characterization methods in dietary fiber preparations. Front Nutr. https://doi.org/10.3389/fnut.2019.00127

16. Bunzel M, Ralph J, Marita JM et al (2001) Diferulates as structural components in soluble and insoluble cereal dietary fibre. $\mathrm{J}$ Sci Food Agric 81:653-660

17. Schmid V, Trabert A, Keller J et al (2021) Functionalization of enzymatically treated apple pomace from juice production by extrusion processing. Foods. https://doi.org/10.3390/foods10030 485 
18. Gniechwitz D, Reichardt N, Blaut M et al (2007) Dietary fiber from coffee beverage: degradation by human fecal microbiota. J Agric Food Chem 55:6989-6996

19. Sweet DP, Shapiro RH, Albersheim P (1975) Quantitative-analysis by various GLC response-factor theories for partially methylated and partially ethylated alditol acetates. Carbohyd Res 40:217-225

20. Anderson RA (1982) Water absorption and solubility and amylograph characteristics of roll-cooked small grain products. Cereal Chem 59:265-269

21. Brands CMJ, Van Boekel MAJS (2002) Kinetic modeling of reactions in heated monosaccharide-casein systems. J Agric Food Chem 50:6725-6739. https://doi.org/10.1021/jf011164h

22. Schmid V, Steck J, Mayer-Miebach E et al (2020) Impact of defined thermomechanical treatment on the structure and content of dietary fiber and the stability and bioaccessibility of polyphenols of chokeberry (Aronia melanocarpa) pomace. Food Res Int 134:109232. https://doi.org/10.1016/j.foodres.2020.109232

23. Emin MA, Wittek P, Schwegler Y (2021) Numerical analysis of thermal and mechanical stress profile during the extrusion processing of plasticized starch by non-isothermal flow simulation. J Food Eng 294:110407. https://doi.org/10.1016/j.jfoodeng. 2020.110407

24. Mohamed IO, Ofoli RY, Morgan RG (1990) Modeling the average shear rate in a co-rotating twin screw extruder. J Food Process Eng 12:227-246

25. Todd DB (1975) Residence time distribution in twin-screw extruders. Polym Eng Sci 15:437-443. https://doi.org/10.1002/pen. 760150607

26. Redgwell RJ, Curti D, Gehin-Delval C (2008) Physicochemical properties of cell wall materials from apple, kiwifruit and tomato. Eur Food Res Technol 227:607-618. https://doi.org/10.1007/ s00217-007-0762-1

Publisher's Note Springer Nature remains neutral with regard to jurisdictional claims in published maps and institutional affiliations.

\title{
Authors and Affiliations
}

\author{
Vera Schmid $^{1} \cdot$ Antje Trabert $^{2} \cdot$ Judith Keller $^{2} \cdot$ Mirko Bunzel $^{2} \cdot$ Heike P. Karbstein $^{1} \cdot$ M. Azad Emin ${ }^{1}$ \\ 1 Institute of Process Engineering in Life Sciences, \\ Chair of Food Process Engineering, Karlsruhe Institute \\ of Technology (KIT), Karlsruhe, Germany \\ 2 Institute of Applied Biosciences, Department of Food \\ Chemistry and Phytochemistry, Karlsruhe Institute \\ of Technology (KIT), Karlsruhe, Germany
}

